\title{
Cognitive-behavioral therapy in generalized anxiety disorder
}

\author{
Burda Hanna ${ }^{1 \mathrm{a}}$ \\ ${ }^{a}$ Bogomolets National Medical University, Kyiv, Ukraine
}

\begin{abstract}
Background. Generalized anxiety disorder - is a common disease, which is quite difficult diagnosed and treated. Cognitive-behavioral therapy is indicated to patients with GAD as a first-line method. This article provides an overview of the principles, advantages and evidence of the effectiveness of this type of therapy. Although cognitive behavioral therapy has advantage over other types of therapy for GAD, this issue requires further research, because there are problems such as a high percentage of patients interrupting therapy and relatively low percentage of clinically meaningful improvement.
\end{abstract}

Keywords: GAD, treatment, methods, CBT, research, anxiety, psychotherapy, efficacy

\section{1. Актуальність}

Тривога є однією із найбільш частих причин звернень пацієнтів до мережі первинної ланки медичної допомоги. Окрім того, велика частка соматичних скарг пацієнтів також спровокована підвищеним рівнем тривоги $[<1>]$. Дані, отримані в рамках обсерваційних досліджень, вказують на те, що, в порівнянні з іншими тривожними розладами, особи з генералізованим тривожним розладом (ГТР) є найбільш активними користувачами послуг фахівців первинної медичної мережі (особливо це стосується послуг кардіологів і гастроентерологів). За даними різних досліджень близько $70 \%$ цих пацієнтів зверталися до лікарів $[<2>]$, що суттєво частіше, ніж, наприклад, пацієнти з депресивними розладами $[<3>]$. При цьому, лише $14 \%$ були проконсультовані фахівцями в галузі психічного здоров'я $[<4>]$ i менш ніж 10\% отримали адекватну психологічну або психофармакологічну допомогу $[<\underline{5}>]$.

Згідно із Міжнародною класифікацією хвороб 10го перегляду (MKX-10) ГТР характеризується стійкою та поширеною тривогою, яка не обмежується якоюсь однією обставиною. Надмірна тривога та переживання в цьому випадку виникають з приводу великої кількості подій або видів активності. Діагностичні критерії ГТР змінювались разом із зміною переглядів на етіологію та патогенез розладу. Варто виокремити діагностичні критерії згідно MKX-10 та DSM-5. Незважаючи на те,

\footnotetext{
${ }^{1}$ (C) Burda H., 2017. This article is distributed under the terms of the Creative Commons Attribution License, which permits unrestricted use and redistribution provided that the original author and source are credited.
}

що в Україні для постановки діагнозу згідно із нормативними документами слід використовувати критеpiї ВО3, Діагностична та статистична настанова психічних розладів Американської психіатричної асоціації $€$ надзвичайно актуальною, оскільки на її основі побудована більшість клінічних шкал для оцінки цього розладу. Це не можна не враховувати при постановці діагнозу.

Огляд критеріїв MKX-10 («Diagnostic criteria for research») вказаний в 1. Слід зазначити, що станом на сьогодення дослідницькі діагностичні критерії МKX-10 iз рубрики розладів психіки та поведінки досі не перекладені на українську мову.

DSM-5 відрізняється тим, що надає значно менший спектр симптомів. Зокрема для констатації ГТР необхідна наявність хоча б $3 x$ (а для дітей лише 1) із нижчезазначених симптомів $[<\underline{6}>]$ :

1. Непосидючість, психічна напруженість або відчуття, ніби «знаходишся на краю».

2. Підвищена втомлюваність.

3. Труднощі із зосередженістю або відчуття пустоти думок.

4. Роздратованість.

5. М'язова напруженість.

6. Порушення сну (труднощі із засинанням, нічні прокидання, сон не приносить відпочинку).

Як можна помітити, в DSM-5 відсутні, наприклад, симптоми, перехресні із панічним розладом (страх втрати контролю, зійти з розуму та страх смерті) або симптоми гіперактивації симпатичної нервової системи, які характерні для панічного розладу та соматоформних розладів. 
Табл. 1: Перелік симптомів ГТР згідно із MKX-10 [5]

\begin{tabular}{|c|c|}
\hline \multicolumn{2}{|c|}{$\begin{array}{c}\text { А. Напруга, переживання, відчуття тривоги з приводу повсякденних } \\
\text { подій та проблем протягом } 6 \text { місяців }\end{array}$} \\
\hline \multicolumn{2}{|c|}{ В. Наявність хоча б одного із нижчеперерахованих симптомів } \\
\hline \multirow[t]{4}{*}{ Симптоми вегетативного збудження } & Відчуття серцебиття, прискорення частоти серцевих скорочень \\
\hline & Потіння \\
\hline & Тремтіння \\
\hline & Сухість у роті (не через прийом препаратів або зневоднення) \\
\hline \multirow[t]{4}{*}{$\begin{array}{l}\text { Симптоми зі сторони грудної клітки } \\
\text { або черевної порожнини }\end{array}$} & Утруднене дихання \\
\hline & Відчуття задухи \\
\hline & Біль у грудях або дискомфорт \\
\hline & Нудота або абдомінальний дистрес \\
\hline \multirow[t]{4}{*}{ Симптоми зі сторони мозку } & Відчуття запаморочення, хиткість, млявість \\
\hline & $\begin{array}{c}\text { Відчуття того, що об’єкти навколо нереальні (дереалізація), або того, що } \\
\text { людина спостерігає себе ніби зі сторони (дереалізація) }\end{array}$ \\
\hline & Страх втрати контролю або зійти з розуму \\
\hline & Страх смерті \\
\hline \multirow[t]{2}{*}{ Загальні симптоми } & Приливи жару або холоду \\
\hline & Заніміння або відчуття поколювання \\
\hline \multirow[t]{4}{*}{ Симптоми напруги } & Напруга у м’язах, ломота або біль \\
\hline & Непосидючість, неможливість розслабитись \\
\hline & Психічна напруженість, відчуття ніби «на краю» \\
\hline & Відчуття кому у горлі або труднощі при ковтанні \\
\hline \multirow[t]{4}{*}{ Інші неспецифічні симптоми } & Надмірна реакція на незначні події, відчуття «на взводі» \\
\hline & Труднощі у концентрації або порожність думок через переживання \\
\hline & Постійна роздратованість \\
\hline & Труднощі із засинанням через переживання \\
\hline \multicolumn{2}{|c|}{$\begin{array}{r}\text { С. Порушення не відповідає критеріям для панічного розладу, фобічного тривожного розладу, } \\
\text { обсесивно-комульсивного розладу або іпохондричного розладу }\end{array}$} \\
\hline \multicolumn{2}{|c|}{$\begin{array}{c}\text { D. Порушення не спровоковане фізичною хворобою, наприклад гіпертиреоїдизмом, вживанням } \\
\text { психоактивних речовин }\end{array}$} \\
\hline
\end{tabular}

Хоча дослідники присвятили вже чимало уваги цьому розладу $[<\underline{7}>;<\underline{8}>;<\underline{9}>]$, до сих пір серед фахівців існує думка про те, що ГТР є відносно легким захворюванням. Однак сучасні дані спростовують такий погляд. ГТР вкрай негативно впливає на якість життя. Такі пацієнти значно частіше, в порівнянні зі здоровими людьми, залишаються самотніми або розлучаються, частіше бувають непрацездатними та мають менший прибуток протягом року $[<10>]$. Питанням значущості ГТР для якості життя і працездатності науковці займалися в рамках «MIDUS survey», за підтримки фонду Макартурів. Дослідження було спрямовано на оцінку як психічних, так і соматичних захворювань $[<11>]$. В ході нього було складено список з п'яти розладів, пов'язаних 3 найбільшою кількістю днів непрацездатності протягом останнього місяця, який очолив ГТР - 6 днів (тиреоїдні розлади - 5,8 днів; туберкульоз - 5,4 дня; варикоз - 5,4 дня, панічний розлад - 5,3 дня). Обидва тривожних розлади, які увійшли до цієї п'ятірки, генерализирований і панічний, увійшли і в велику шістку розладів з найбільш сильним негативним впливом на працездатність. Але на особливе місце в наукових дослідженнях ГТР претендує ще в силу того, що має найбільшу резистентність до лікування, порівняно з усіма тривожними розладами.

\section{2. КБТ при генералізованому тривожному роз- ладі}

\section{1. Типові техніки}

Особливе місце в лікуванні ГТР займає когнітивноповедінковий підхід. При роботі 3 хворими на ГТР успішно застосовуються багато класичних технік когнітивно-біхевіоральної терапії (КБТ). Щодо когнітивного компоненту КБТ, однією із базових $є$ техніка, спрямована на виявлення тригерів занепокоєння, формулювання характерних для тривожності автоматичних думок в провокуючих ситуаціях і на побудову альтернативного погляду на ці ситуації. Ця техніка базується на класичних роботах А. Елліса щодо формули $\mathrm{ABC}$, де А - активуюча подія, В - оцінка події, переконання щодо неї та $\mathrm{C}$ - наслідки у вигляді емоцій та 
поведінки. Вважається, що причиною депресивних та тривожних розладів є ірраціональні переконання, які формуються внаслідок когнітивних помилок (викривлень). Ці переконання лежать в основі й патологічної тривоги. Основна робота з пацієнтом базується на ідентифікації цих дисфункціональних переконань та заміна їх на раціональні. Таким чином інтенсивність тривоги знижується $[<12>;<13>;<14>]$.

Для досягнення цього в арсеналі психотерапевта, який притримується КБТ, є цілий арсенал когнітивних технік: «Визначення переконань», «Групування переконань», різноманітні техніки спростування, «Ресинтез минулого» та інші; а також поведінкових: «Прогресивна м'язова релаксація за Джекобсоном», «Систематична десенсибілізація», «Наводнення», різновиди позитивного та негативного підкріплення тощо.

Слід зазначити, що високий відсоток хворих, які переривають психотерапію, висока резистентність до лікування спонукали дослідників до пошуків більш специфічних форм роботи, заснованих на специфічних моделях ГТР. Модель канадських вчених визнана найбільш повною і добре обгрунтованою $[<11>]$. Вона включає чотири компоненти - предиктори ГТР, які одночасно є найважливішими мішенями психотерапії:

1. низька толерантність до невизначеності;

2. позитивні переконання щодо занепокоєння;

3. відсутність орієнтації на вирішення проблем;

4. когнітивне уникнення.

Протокол лікування включає шість модулів:

1. Психоосвітній модуль, спрямований на розуміння суті і краще усвідомлення власного занепокоєння;

2. Модуль, спрямований на усвідомлення власної низької толерантності до невизначеності і на застосування методу експозиції з метою тренування здатності терпіти невизначеність;

3. Тренінг вирішення проблем;

4. Модуль, спрямований на подолання когнітивного уникнення і розвиток здатності виносити неприємні образні уявлення на основі методу експозиції;

5. Профілактика рецидивів захворювання.

Слід зазначити, що ефективність цього протоколу визначалась в рамках досліджень, де продемонструвала доволі високу дієвість $[<15>]$.

\section{2. Психоосвіта (психоедукація)}

Психосовіта є невід'ємною частиною роботи з пацієнтом при використання будь-якого когнітивного підходу. Окрім того, психоосвіта включена у якості першої лінії терапії (перед призначенням інтенсивних психологічних інтервенцій) при лікуванні ГТР у найбільш авторитетних клінічних настановах, наприклад NICE $[<16>]$.

Зазвичай вона спрямована на розуміння суті й усвідомлення тривоги та включає надання інформації про суть когнітивно-біхевіоральної терапії як ефективного методу лікування тривожних розладів; інформацію про природу ГТР, включаючи його опис та характеристики, насамперед схильність до хронічного перебільшеного й погано контрольованого неспокою; уявлення когнітивної моделі ГТР і «нормалізацію» його симптомів як лише перебільшене вираження того, що є і в нормі; тренінг по усвідомленню тривоги, який включає регулярні записи (три рази на день) інформації про те, яку саме тривогу відчуває пацієнт і яка тема цього занепокоєння, в тому числі фіксація тимчасової спрямованості (відношення тривоги до сьогоднішніх проблем або ж до можливих майбутніх).

\section{3. Самоусвідомлення та експозиція}

Підвищення самоусвідомлення, особливо в контексті поведінки, яка підтримує проблеми (в даному випадку - уникнення), та експозиція до ситуацій (in vivo або in sensu), які призводять до інтенсивної тривоги, також є стандартними техніками при роботі з ГТР $[<17>;<18>]$. Хоча щодо експозиції, вона не займає таке центральне місце, як, наприклад, при терапї панічного розладу або посттравматичного стресового розладу. У ході Сократівського діалогу важливо дати клієнту дійти до усвідомлення власної низької толерантності до невизначеності, розуміння зв'язку між низькою толерантністю до невизначеності і перебільшеним занепокоєнням. Допомогу в усвідомленні неминучості вибору між уникненням і хворобою з одного боку і розвитком здатності переносити невизначеність та повноцінним життям - $з$ іншого.

Окрім того, проводиться робота з виявлення ситуацій, які провокують стан занепокоєння з приводу невизначеності, і занурення в них на основі методу експозиції. При цьому слід мати на увазі, що як надмірно інтенсивні переживання при експозиції, так і їх відсутність $\epsilon$ негативним моментом, який потребує додаткового регулювання глибини експозиції. Цей метод спрямований на подолання когнітивного уникнення та вироблення здатності переносити неприємні почуття і образи. Він передбачає обговорення образів ситуацій, що лякають, опис почуттів і суб'єктивну оцінку рівня тривоги та тренування стійкості до цих образів і почуттів на основі методу експозиції. Для збільшення рівня емоційного збудження зазвичай просять пацієнта більш детально уявити та описати ситуацію, в декількох сенсорних модальностях. Для зменшення - уявити та описати від третьої особи, уявити, ніби пацієнт спостерігає за ситуацією на екрані телевізора тощо.

Часто використовується систематична десенсибілізація, яка поєднується із техніками релаксації. Пацієнт складає перелік подій, які викликають тривогу, ранжує ïx у порядку зростання неприємних відчуттів, а потім проводиться поступова покрокова експозиція, яка супроводжується релаксацією. 


\section{4. Когнітивне реструктурування}

Когнітивне реструктурування при ГТР спрямоване на переоцінку цінності занепокоєння та передбачає виявлення всіх аргументів на користь тривоги; виявлення контраргументів і аналіз негативних наслідків тривоги для життя пацієнта; формулювання нових переконань щодо тривоги як неефективної стратегії боротьби з небезпекою. При роботі на цьому етапі дуже важливо зафіксувати, що тривога може бути корисною і реально допомагати передбачати небезпеку. Однак у здорових людей занепокоєння має інший, більш конструктивний характер. У хворих можлива користь від тривоги повністю перекривається їі негативними наслідками, які значно перевищують можливу користь.

Для когнітивного реструктурування широко застосовується сбір доказів, експериментальне підтвердження в реальних ситуаціях, аналіз «переваг та недоліків» (в оригіналі «cost/benefit»), ідентифікацію когнітивних помилок, створення альтернативних пояснень, рефреймінг/розгляд перспектив (акцентується в майндфулнес когнітивній терапії) тощо $[\langle 19>;<20>;<21>]$.

\section{5. Вирішення проблем}

«Problem solving» або вирішення проблем спрямоване на підготовку до неминучості невизначеності в процесі вирішення проблем $[<22>]$. Окрім того, в ході психотерапевтичної роботи проводять визначення існуючих проблем та формулювання цілей щодо їх подолання, вироблення різних можливих шляхів досягнення цих цілей, вибір найбільш прийнятного шляху, застосування вироблених засобів і оцінку результату $[<23>]$. Тут працює простий принцип: вирішувати реальні проблеми краще, ніж нескінченно турбуватися про всі ймовірні.

Детально «problem solving» описане в роботах M. Eskin (2012). Автор методики пропонує починати 3 оцінки проблем, пояснення теоретичного підгрунтя технік та плану занять. Окремо виділяється так званий тренінг відношення до проблем («problem orientation training»), коли необхідно допомогти пацієнту усвідомити проблему та виробити здатність дивитись на проблему у позитивному руслі. Під визначенням проблем автор розуміє навчання пацієнта ідентифікації та визначенню емоційний симптомів, спричинених проблемами (проблема -> емоція), формулюванню проблем (особисті, міжособистісні, матеріальні тощо). При цьому можна використовувати різні техніки, наприклад ідентифікацію проблемних ситуацій, метод скринінгу, в якому психотерапевт відмічає рівень дистресу пацієнта при розповіді про ту чи іншу ситуацію, метод «стій-таподумай», орієнтований на навчання пацієнта відмічати свої емоційні сигнали та техніку Лазаруса, в якій психотерапевт просить пацієнта змалювати проблему одним словом. Наступний крок, - встановлення цілей, - є важливим компонентом вирішення проблем, оскільки допомагає направити увагу та поведінку пацієнта в «одну точку», активує зусилля, мотивує та підтримує. При генеруванні можливих рішень проблем пацієнту пропонують вказати стільки рішень, скільки можливо при даній проблемі. Для цього можна використовувати техніку мозкового штурму, рефреймінг (його також включає когнітивне реструктурування), метод «поради другу» та метод «бути супергероєм». Для вибору доречного вирішення проблеми автор рекомендує проводити аналіз переваг та недоліків (також є частиною когнітивного реструктурування), порівнювати альтернативи одну з одною, оцінювати персональні та соціальні ресурси клієнта. Оскільки пацієнти можуть мати страхи $з$ приводу імплементації рішення, важливо скласти перелік позитивних та негативних наслідків використання даного рішення, а також позитивні та негативні наслідки не використання цього рішення $[<24>]$.

Наразі цей підхід із сукупності технік переріс у цілий психотерапевтичний напрямок в КБТ. Його можна використовувати двома способами. По-перше, він може використовуватись для терапії психологічних проблем, спричинених експозицією до проблемних ситуацій. Та, по-друге, він може слугувати профілактикою для майбутніх проблем, з якими потенційно може стикатись пацієнт та які можуть призвести до негативних емоційних реакцій.

\section{6. Профілактика рецидивів}

Зазвичай кінцевий етап (робота з пацієнтом згідно настанов по КБТ) включає профілактику рецидивів ГТР. Ця робота складається із закріплення всіх отриманих знань і навичок, обговорення з пацієнтом можливих тригерів і провокацій, які можуть сприяти поверненню старого неефективного стилю подолання у вигляді постійної тривоги і уникнення конструктивного вирішення проблем та обговорення способів поведінки в цих ситуаціях.

\section{3. Докази ефективності КБТ}

Ефективність КБТ інтенсивно вивчалась в рамках численних досліджень. 3 одного боку, проводилось порівняння із плацебо-інтервенціями, які підтвердили їі дієвість . 3 іншого - були проведені дослідження, в яких ефективність КБТ порівнювалась з іншими видами психотерапії, такими як психодинамічна та деякими іншими. Питання щодо порівняння ефективності видів психотерапевтичних інтервенцій завжди знаходиться в центрі дискусій між представниками різних психотерапевтичних шкіл. Дійсно, порівняти дієвість методів загалом, для всіх пацієнтів та станів, не представляється можливим. Жодне дослідження чи систематичний огляд не має можливості за допомогою статистичних методів порівнювати настільки гетерогенні показники. Таких методів статистики просто не існує.

3 іншого боку, порівняти ефективність методів лікування при одному, чітко окресленому, стані - це завдання, яке можна і навіть треба виконувати. Перш за 
Табл. 2: Типова програма підходу «вирішення проблем» [24].

\begin{tabular}{|c|c|}
\hline Структурний компонент & Коментар та техніки \\
\hline $\begin{array}{c}\text { Оцінка та } \\
\text { пояснення теорії } \\
\text { вирішення проблем }\end{array}$ & Інформування пацієнта підвищує його мотивацію \\
\hline $\begin{array}{l}\text { Тренінг відношення } \\
\text { до проблем }\end{array}$ & $\begin{array}{c}\text { Усвідомлення проблем, вироблення позивної орієнтації до } \\
\text { проблем, проблеми - це звичайний компонент життя }\end{array}$ \\
\hline Визначення проблем & $\begin{array}{c}\text { Ідентифікація емоційних симптомів, ідентифікація } \\
\text { проблемних ситуацій, метод скринінгу, техніка «стій-та-подумай», техніка } \\
\text { Лазаруса }\end{array}$ \\
\hline Постановка цілей & $\begin{array}{c}\text { Цілі щодо проблемних ситуацій, цілі щодо емоцій та } \\
\text { дистресу, визначення ресурсів, необхідного часу, людей, які можуть } \\
\text { забезпечити підтримку тощо }\end{array}$ \\
\hline $\begin{array}{l}\text { Генерування всіх } \\
\text { можливих варіантів } \\
\text { вирішення }\end{array}$ & $\begin{array}{c}\text { Метод мозкового штурму, рефреймінг, метод поради } \\
\text { другу, метод «бути героєм» }\end{array}$ \\
\hline $\begin{array}{l}\text { Вибір доречного } \\
\text { вирішення }\end{array}$ & $\begin{array}{c}\text { Аналіз переваг та недоліків, порівняння альтернатив } \\
\text { між собою, оцінка персональних і соціальних ресурсів, оцінка } \\
\text { прийнятності рішення }\end{array}$ \\
\hline Імплементація & $\begin{array}{c}\text { Позитивні та негативні наслідки імплементації, позитивні та } \\
\text { негативні наслідки не використання цього вирішення, робота зі страхом } \\
\text { перед прийняттям рішення }\end{array}$ \\
\hline $\begin{array}{l}\text { Оцінка результатів } \\
\text { імплементації }\end{array}$ & $\begin{array}{c}\text { Чи досягнуто цілі? Якщо ні, чи ці цілі реалістичні? } \\
\text { Чи правильне рішення вибрано? тощо }\end{array}$ \\
\hline
\end{tabular}

все, слід згадати результати Кокранівського систематичного огляду, присвяченого порівнянню дієвості психологічних методів лікування ГТР $[<15>]$. Нагадаєм, що Кокранівські систематичні огляди та мета-аналізи проводяться незалежними вченими зі всього світу на добровільній основі. Таким чином забезпечується відсутність конфлікту інтересів та особистої зацікавленості дослідників. За кожною групою, яка проводить огляд, спостерігає редакторський колектив з відповідної галузі. Аналіз проводиться згідно із статистичною настановою Кокранівського співробітництва.

Порівнювались між собою такі види психотерапії: когнітивно-поведінкова, психодинамічна, активна підтримуюча (роджеріанська, гештальт-терапія, транзактний аналіз, психологічне консультування) та неактивна підтримуюча (плацебо інтервенції). Спочатку дослідники порівнювали кожен вид психотерапії iз стандартною терапією («treatment as usual») та листом очікування (пацієнти, які чекали на лікування, тобто відсутність лікування). Потім аналізували ефективність різних методів між собою.

В аналіз відібрали всі доступні якісні дослідження, проведені у цій сфері. Після детального огляду були відібрані 25 робіт, із яких в остаточний аналіз включили 22. Основні результати представлені в 3 та 4 . Детально зупинимся на показниках.

Відносний ризик (BP, в цьому випадку об'єднаний відносний ризик) - це показник, який вираховується на основі ймовірності досягнення якого-небудь дихото- мічного результату. При цьому спочатку порівнюють ефективність кожного методу у відношенню до контролю для кожного дослідження, а потім підраховують вже співвідношення ефективності між психотерапевтичними методами. Наприклад, відносний ризик щодо клінічної відповіді між КБТ та підтримуючою терапією складає 0,90. Клінічна відповідь - це дихотомічна змінна. Або пацієнт досягає клінічної відповіді, якщо за клінічною шкалою (в даному випадку Шкала оцінки депресії Гамільтона) кількість набраних балів наприкінці лікування на 50\% менше, ніж на початку, або ні. Отже ймовірність досягнення клінічної відповіді в групі підтримуючої терапії складає 0,90 від такого в групі КБТ, тобто на $10 \%$ менше.

Різниця середніх (PC) - це просте порівняння середніх показників (балів) за набраною шкалою між двома групами. Наприклад, якщо в ході лікування в групі КБТ середня кількість балів за шкалою Гамільтона зменшилась на 10 балів, а в групі психодинамічної терапії на 3,15 бали, то різниця середніх буде складати $3,15-10$, тобто -6,85 бали. Цей показник можна використовувати, якщо в різних дослідженнях використовувалась одна й та сама шкала. В даному випадку Шкала оцінки депресії Гамільтона.

Стандартизована різниця середніх (CPC) - це різниця між середніми показниками (балами) за набраними шкалами, виражена у одиницях стандартного (стандартизованого) відхилення. Перевага цього показника над попереднім у тому, щоб він дозволяє порівнювати ба- 
ли, набрані за різними шкалам, які оцінюють одне й явище (в даному випадку вираженість тривоги, соціальне функціонування тощо). Для його розрахунку різницю середніх по кожній шкалі ділять на стандартне відхилення по показнику. Для того, щоб його зрозуміти та проінтерпретувати слід згадати криву нормального розподілення та яку ширину там займає одне стандартне відхилення. В цьому мета-аналізі використовували метод Коєна для підрахунку розміру ефекту на основі CPC (Cohen's d). Загалом, прийнято вважати, що CPC за методом Коєна на рівні 0,2 або більше вказує на малий розмір ефективну або малу різницю між методами лікування, які порівнюються, 0,5 або більше - на середній розмір ефекту та 0,8 або більше - на великий розмір ефекту між порівнюваними групами.

Розуміння цих показників робить інтерпретацію будь-якого мета-аналітичного дослідження доволі легким завданням. На рахунок вищезгаданого Кокранівського систематичного огляду з мета-аналізом, ми можем побачити значні переваги КБТ перед підтримуючими видами терапії (3) та психодинамічною терапією (4) в контексті лікування ГТР. Наприклад, СРС для основних симптомів ГТР в першому випадку коливалась в межах від -0,72 до -0,37. Тобто розмір ефекту у підтримуючої терапії в порівнянні з КБТ по цьому показнику був менший на 0,37 (тривога) та 0,72 (стурбованість, переживання), що означає малий та середній розмір ефекту відповідно. Порівняння цих методів психотерапії продемонструвало, що ймовірність клінічної відповіді через 6 місяців після завершення лікування КБТ була на $22 \%$ вища, ніж у групі підтримуючої терапії.

Варто окремо вказати й абсолютні показники, які не увійшли в дані таблиці. Так, наприклад, коли пацієнтів обстежували через 6 місяців після лікування, то клінічна відповідь, тобто зменшення кількості балів за клінічною шкалою на $50 \%$ або більше балів від початку лікування, спостерігалась у $39 \%$ пацієнтів із групи КБТ та у $23 \%$ - із групи психодинамічної психотерапії. Коли таке саме порівняння зробили для КБТ та підтримуючої терапії, то підраховані показники склали $42 \%$ та $28 \%$ відповідно, але цього разу оцінювали пацієнтів, які мали клінічну відповідь одразу після лікування.

Які можна зробити висновки, базуючись на цих даних? По-перше, увагу привертає доволі невеликий відсоток пацієнтів, які відповідають на лікування. У кращому випадку це трохи менше половини всіх, хто проходить лікування. Хоча тут слід додати, що мова йде про клінічну відповідь. Більша частина тих, хто не досягає клінічної відповіді, все ж має покращення у симптомах ГТР та якості життя.

По-друге, порівняно з психодинамічним підходом, гештальт-терапією, транзактним аналізом та роджеріанським підходом, КБТ є найбільш ефективним методом лікування пацієнтів із ГТР. Чому ж мова йде лише про окремі методи, а не про всі можливі види психотерапії? Відповідь доволі проста - станом на момент про- ведення цього Кокранівського систематичного огляду, якісних досліджень, в яких би оцінювалась ефективність інших методів при ГТР, просто не було опубліковано. Таким чином, враховуючи підхід доказової медицини, використання всіх інших методів при ГТР є суто експериментальним, тобто зовсім не було дослідженим, та не має доведеної ефективності.

Слід, однак, зазначити, що в 2014 році було проведено ще одне мета-аналітичне дослідження, в якому порівнювались різні психологічні методи лікування ГТР $[<25>]$. В нього включили додатково ще 2 дослідження, опублікованих з 2010 року, які були присвячені іншим психотерапевтичним методам - «acceptance and commitment therapy» (терапія прийняття, підвид майндфулнес КБТ) та духовна терапія (spiritual therapy). На жаль, автори цього мета-аналізу не представили таких чітких інтерпретацій, як автори попереднього Кокранівського систематичного огляду. Основні результати представлені в (5).

Таким чином, позитивний розмір ефекту в даному мета-аналізі вказує на більшу ефективність КБТ. В цьому разі КБТ порівнювалась із іншими методами (на відміну від попереднього систематичного огляду, в якому інші методи порівнювались із КБТ). Розмір ефекту менше, ніж 0,2, вказує на незначну відмінність між методами. Це справедливо при порівнянні КБТ та тільки технік релаксації. Релаксаційні техніки зазвичай $є$ частиною КБТ але автори вирішили провести окремий аналіз ефективності для них. Теж с саме стосується КБТ та фармакотерапії. А от що стосується інших методів, тут КБТ безперечно продемонструвала кращі результати. Однак автори детально не зазначили, які саме методи були віднесені до біофідбек методів («acceptance and commitment therapy»?), а які до підтримуючих (мотиваційне інтерв'ю, духовну терапію, гештальт?).

\section{4. Висновки}

Генералізований тривожний розлад в силу своїх особливостей, - серйозна проблема, з якою стикається все більша кількість людей. Постійні стреси, перенавантаження, конфлікти, які постійно супроводжують громадян, є стимулюючими факторами в розвитку ГТР. На основі рандомізованих контрольованих досліджень було доведено, що КБТ є більш ефективною за інші види психотерапевтичних інтервенцій та, як мінімум, не менш ефективною ніж фармакотерапія.

КБТ, направлена на лікування ГТР, має широкий вибір психологічних технік, які можуть використовуватись у різних «дозах» та комбінаціях. Це дозволяє, незважаючи на високу структурність методу, індивідуалізувати підхід для кожного окремого пацієнта. Однак, слід додати, що навіть КБТ не є ідеальним засобом від ГТР, оскільки доволі великий відсоток пацієнтів не отримують клінічно значимої відповіді на це лікування. 
Psychosomatic Medicine and General Practice • Feb $2017 \bullet$ Vol.2(1) • e020117

Табл. 3: КБТ та активна підтримуюча терапія (гештальт, роджеріанська, транзактний аналіз) [15].

\begin{tabular}{|c|c|c|c|c|}
\hline Результат & $\begin{array}{c}\text { К-ть } \\
\text { досліджень }\end{array}$ & $\begin{array}{c}\text { К-ть } \\
\text { досліджуваних }\end{array}$ & $\begin{array}{c}\text { Статистичний } \\
\text { метод }\end{array}$ & $\begin{array}{c}\text { Розмір ефекту, } \\
\mathbf{9 5 \%} \text { ДІ *** }\end{array}$ \\
\hline \hline $\begin{array}{c}\text { Клінічна відповідь } \\
\text { (Шкала Гамільтона ) }\end{array}$ & 5 & 208 & BР* & $0,90(0,70-1,16)$ \\
\hline $\begin{array}{c}\text { Зменшення симптомів тривоги } \\
\text { (Шкала Гамільтона, ADIS-R) }\end{array}$ & 5 & 136 & СРС** & $-0,37(-0,66 \ldots-0,14)$ \\
\hline $\begin{array}{c}\text { Зменшення симптомів } \\
\text { стурбованості (РSWQ, FQ, FS) }\end{array}$ & 3 & 92 & СРС & $-0,72(-1,15 \ldots-0,29)$ \\
\hline $\begin{array}{c}\text { Клінічна відповідь } \\
\text { через 6 місяців } \\
\text { (Шкала Гамільтона) }\end{array}$ & 2 & 106 & $\mathrm{BP}$ & $0,78(0,54-1,13]$ \\
\hline $\begin{array}{c}\text { Зниження симптомів тривоги } \\
\text { через 6 місяців }\end{array}$ & 2 & 62 & $\mathrm{CPC}$ & $-0,39(-0,90 \ldots ., 11)$ \\
\hline \hline
\end{tabular}

*BP - відносний ризик; ** СРС - стандартизована різниця середніх; ***95\% ДІ - 95\% довірливий інтервал. Пояснення показників в текст статті.

Табл. 4: КБТ і Психодинамічна терапія [15].

\begin{tabular}{|c|c|c|c|c|}
\hline Результат & $\begin{array}{c}\text { Кількість } \\
\text { досліджень }\end{array}$ & $\begin{array}{c}\text { Кількість } \\
\text { досліджуваних }\end{array}$ & $\begin{array}{c}\text { Статистичний } \\
\text { метод }\end{array}$ & $\begin{array}{c}\text { Розмір ефекту } \\
(\mathbf{9 5 \%} \text { ДІ***) }\end{array}$ \\
\hline Клінічна відповідь & 1 & 110 & ВР* $^{*}$ & $0,77(0,65-0,92)$ \\
\hline Зниження симптомів тривоги & 2 & 64 & РС** & $-6,85(-11,20 \ldots 2,50)$ \\
\hline Зниження симптомів депресії & 2 & 64 & PC & $-8,37(-12,55 \ldots 4,20)$ \\
\hline $\begin{array}{c}\text { Покращення соціального } \\
\text { функціонування }\end{array}$ & 2 & 64 & $\mathrm{PC}$ & $14,28(1,82 \ldots 26,75)$ \\
\hline $\begin{array}{c}\text { Клінічна відповідь через } \\
6 \text { місяців }\end{array}$ & 1 & 110 & $\mathrm{PC}$ & $-13,41(-19,09 \ldots 7,74)$ \\
\hline $\begin{array}{c}\text { Зниження тривожних симптомів } \\
\text { через 6 місяців }\end{array}$ & 2 & 55 & $0,62 \ldots 1,01)$ \\
\hline
\end{tabular}

*BP - відносний ризик; **РC - різниця середніх; ***95\% ДІ - 95\% довірливий інтервал. Пояснення показників в тексті статті.

На сьогоднішній день когнітивно-поведінкова терапія у США та Великобританії є методом лікування першої лінії при наданні допомоги пацієнтам з тривожнодепресивними розладами та, зокрема ГТР. Відповідні рекомендації вказані в настановах Національного інституту здоров'я та клінічного удосконалення (NICE, Великобританія) та Американської психіатричної асоціації (АРА, США).

\section{References}

1. Kroenke K, Spitzer R, Williams J, Linzer M, Hahn S, deGruy F, Brody D. Physical symptoms in primary care. predictors of psychiatric disorders and functional impairment. Archives of Family Medicine 1994-sep;3(9):774-9.

2. Wittchen H, Zhao Z, Kesller R, Eaton W. Dsm-iii-r generalized anxiety disorder in the national comorbidity survey. Archives of General Psychiatry 1994-may;51(5):355-64.

3. Wittchen HU. Generalized anxiety disorder: prevalence, burden, and cost to society. Depression and Anxiety 2002;16(4):162-71. doi $10.1002 /$ da. 10065

4. Hunt C, Issakidis C, Andrews G. Dsm-iv generalized anxiety disorder in the australian national survey of mental health and well-being. Psychological Medicine 2002-may;32(4):649-59.
5. WHO . The ICD-10 Classification if Mental and Behavioural Disorders: Diagnostic criteria for research. Geneva: WHO; 1993. URL: http://www.who.int/classifications/icd/en/ GRNBOOK.pdf

6. APA . Diagnostic and Statistical Manual of Mental Disorders. 5 ed. Arlington: American Psychiatric Publishing; 2013.

7. Aleksandrovskyy I. Rasstroystva pishchevogo povedeniya pri ozhireniii ikh korrektsiya. Trevozhnie rasstroystva. Moskov: GEOTAR-MED; 2004.

8. Veltyshchev D, Marchenko A. Generalizovannoe trevozhnoe rasstroystvo: problemyi diagnostiki, prognoza i psihofarmakoterapiia. Sovremennaya terapiya psihicheskih rasstroystv 2013;1:17-23. URL: http://www . psypharma.ru/ru/ generalizovannoe-trevozhnoe-rasstroystvo-problemy-diagl nostiki-prognoza-i-psihofarmakoterapii

9. Less Y. Generalizovannoe trevozhnoe rasstroystvo: tipologiya i komorbidnyie sostoyaniya. Rossiyskiy psihiatricheskiy zhurnal 2008;2:40-5. URL: http://elibrary.ru/item.asp?id= 10441306

10. Rossi A. Caring and doing for others: social responsibility in the domains of family, work and community. The chronic association between medical conditions and work impairment. Chicago: University of Chicago Press; 2001.

11. D'Zurilla T, Nezu A. Problem-solving therapy: A social competence approach to clinical intervention. New York: Springer; 1999. 
Табл. 5: Порівнянні ефективності КБТ із іншими методами при ГТР [25]

\begin{tabular}{|c|c|c|c|c|}
\hline Порівняння & К-ть досліджень & Розмір ефекту* & $\mathbf{9 5 \%}$ ДІ & NNT** \\
\hline \hline КБТ та релаксаційні техніки & 6 & 0,19 & $-0,22 \ldots 0,60$ & 9,43 \\
\hline КБТ та психодинамічна терапія & 3 & 0,46 & $-0,09 \ldots 1,01$ & 3,91 \\
\hline КБТ та біофідбек методи & 2 & 0,68 & $-0,18 . .1,54$ & 2,70 \\
\hline КБТ та підтримуюча терапія & 2 & 0,48 & $-0,21 \ldots 1,17$ & 3,76 \\
\hline КБТ та фармакотерапія & 2 & 0,18 & $-0,76 \ldots 1,12$ & - \\
\hline \hline
\end{tabular}

*B даному випадку розмір ефекту оцінювався за методом Ларрі Хеджеса (Larry Hedges), a не методом Коєна; NNT - тут це кількість пацієнтів, які треба пролікувати за допомогою КБТ, для досягнення одного додаткового випадку клінічної відповіді у порівнянні із вказаним методом

12. Ellis A. Rational Emotive Behavior Therapy: A Therapist's Guide. 2nd ed. Atascadero: Impact Publishers; 2005.

13. McMullin R. The New Handbook of Cognitive Therapy Techniques. 2nd ed. New York: W. W. Norton Company; 1999.

14. Knaus W. The Cognitive Behavioral Workbook for Anxiety: A Step-by-Step Program. Oakland: New Harbinger Publications; 2008.

15. for Health NI, Exellence C. Generalised anxiety disorder and panic disorder in adults: management. NICE 2011;URL: https : //Www.nice.org.uk/guidance/CG113

16. Hanot V, Churchill R, Teixeira V, Lima S. Psychological therapies for generalized anxiety disorder. Cochrane Database of Systematic Reviews 2007;4. doi 10.1002/14651858.CD001848. pub4

17. Borkovec T, Newman M, Pincus A, Lytle R. A component analysis of cognitive-behavioral therapy for generalized anxiety disorder and the role of interpersonal problems. Journal of Consulting and Clinical Psychology 2002;70(2):288-98. doi 10 . 1037/0022-006X.70.2.288

18. Kaczkurkin A, Foa E. Cognitive-behavioral therapy for anxiety disorders: an update on the empirical evidence. Dialogues in Clinical Neuroscience 2015;17(3):337-46.

19. Beck J, Beck A. Cognitive Behavior Therapy: Basics and Beyond. 2nd ed. New York: Guildford Press; 2011.

20. Clark D, Beck A. Cognitive Therapy of Anxiety Disorders: Science and Practice. New York: Guilford Press; 2011.

21. Dobson K. Handbook of Cognitive-Behavioral Therapies. 3rd ed. New York: Guilford Press; 2009.

22. Segerstrom S, Tsao J, Alden L, Craske M. Worry and rumination: Repetitive thought as a concomitant and predictor of negative mood. Cognitive Therapy and Research 2000;24:67188. doi 10.1023/A: 1005587311498

23. Young S. Cognitive-Behavioural Therapy for ADHD in Adolescents and Adults: A Psychological Guide to Practice. 2nd ed. Hoboken: Wiley-Blackwell; 2012.

24. Eskin M. Problem solving therapy in the clinical practice. Elsevier 2013;.

25. Cuijpers P, Sijbrandij M, Koole S, Huibers M, Berking M, Andersson G. Psychological treatment of generalized anxiety disorder: A meta-analysis. Clinical Psychology Review 2014mar;32(2):130-40. doi 10.1016/j.cpr.2014.01.002 